\title{
Physical and chemical changes in soil fertilized with poultry manure with and without chiseling
}

\author{
Edson S. Eguchi ${ }^{1}$, Ulysses Cecato ${ }^{2}$, Antonio S. Muniz ${ }^{3}$, \\ Gracielle C. Mari ${ }^{2}$, Raphael A. C. Murano ${ }^{4} \&$ Eurico L. de Sousa Neto ${ }^{1}$ \\ ${ }^{1}$ Universidade do Estado de Mato Grosso/Departamento de Zootecnia. Pontes e Lacerda, MT. E-mail: eguchi@unemat.br (Corresponding author); \\ euriconeto@unemat.br \\ ${ }^{2}$ Universidade Estadual de Maringá/Departamento de Zootecnia. Maringá, PR. E-mail: ulyssescecato@gmail.com; gracielle_mari@hotmail.com \\ ${ }^{3}$ Universidade Estadual de Maringá/Departamento de Agronomia. Maringá, PR. E-mail: asmuniz@uem.br \\ ${ }^{4}$ Universidade Estadual de Maringá/Centro de Ciências Agrárias. Maringá, PR. E-mail: rapha_murano@hotmail.com
}

Key words:

palisade grass

fertilization

forage cultivation

residue

\begin{abstract}
A B S T R A C T
Poultry manure and mechanical management may influence the distribution of nutrients in the soil profile. The objective was to evaluate physical and chemical changes in a soil with palisade grass (Brachiaria brizantha cv. Marandu) fertilized with doses of poultry manure with and without use of soil chiseling, after 180 days of application. The design was a randomized blocks with four replicates, in a $5 \times 2$ factorial arrangement with five doses of manure $\left(0,1.073,2.074,4.148\right.$ and $\left.6.222 \mathrm{Mg} \mathrm{ha}^{-1}\right)$, with and without soil chiseling at $0.20 \mathrm{~m}$. Soil chiseling caused physical changes with an increase of macroporosity in the layer of $0-0.2$ $\mathrm{m}$ and reduction in soil density and increase in macroporosity and total porosity in the layer of 0.2-0.4 m. With manure doses, $\mathrm{pH}$ in the layer of $0-0.1 \mathrm{~m}$ showed quadratic fit with maximum value of 7.2. The increases in $\mathrm{Ca}$ and $\mathrm{Zn}$ in the layer of $0-0.1 \mathrm{~m}$ were, respectively, $0.61 \mathrm{cmol} \mathrm{dm}^{-3}$ and $2.99 \mathrm{mg} \mathrm{dm}^{-3}$. In the interaction of Dose $\mathrm{x}$ Management, without soil chiseling, $\mathrm{K}$ showed a linear fit and increased 1.39 times; while in the interaction of Dose $\mathrm{x}$ Management, with soil chiseling in the layers of $0.1-0.2$ and $0.2-0.4 \mathrm{~m}, \mathrm{P}$ increased by 8.10 and $3.95 \mathrm{mg} \mathrm{dm}^{-3}$, respectively. In the contrast between the dose zero and manure dose, there was significance for $\mathrm{pH}, \mathrm{Ca}, \mathrm{P}$ and $\mathrm{Zn}$ in the layer of $0-0.1 \mathrm{~m}$.
\end{abstract}

\section{Palavras-chave:}

braquiária

fertilização

forragicultura

resíduo

\section{Alterações físicas e químicas em solo fertilizado com esterco de galinha em diferentes manejos}

\section{R E S U M O}

O esterco de galinha e o manejo mecânico podem influenciar na distribuição de nutrientes no perfil do solo. O objetivo foi avaliar as alterações físicas e químicas no solo com capim Marandu fertilizado com doses de esterco de galinha sem e com uso de escarificador, após 180 dias de aplicação. O delineamento foi em blocos ao acaso com quatro repetições num arranjo fatorial 5 x 2, com cinco doses de esterco $\left(0,1,037 ; 2,074 ; 4,148 ; 6,222 \mathrm{Mg} \mathrm{ha}^{-1}\right)$ sem e com escarificação a $0,20 \mathrm{~m}$. A escarificação favoreceu alterações físicas com aumento de macroporosidade na camada $0-0,2 \mathrm{~m}$ e redução de densidade do solo e aumento de macroporosidade e porosidade total na camada $0,2-0,4 \mathrm{~m}$. Com doses de esterco o $\mathrm{pH}$ na camada 0-0,1 m teve ajuste quadrático com valor máximo de 7,2. $\mathrm{O}$ aumento nos teores de Ca e Zn na camada 0-0,1 m foi, respectivamente, de $0,61 \mathrm{cmol}_{c} \mathrm{dm}^{-3}$ e de 2,99 $\mathrm{mg} \mathrm{dm}^{-3}$. Na interação dose $\mathrm{x}$ manejo sem escarificação do solo o K teve ajuste linear com aumento de 1,39 vezes enquanto na interação entre dose $\mathrm{x}$ manejo com escarificação nas camadas $0,1-0,2$ e 0,2-0,4 m, o P teve aumento de 8,10 e $3,95 \mathrm{mg} \mathrm{dm}^{-3}$, respectivamente. No contraste entre dose zero com dose de esterco houve significância para $\mathrm{pH}, \mathrm{Ca}, \mathrm{P}$ e $\mathrm{Zn}$ na camada $0-0,1 \mathrm{~m}$. 


\section{INTRODUCTION}

As in all the regions of the country, in Northeastern Paraná, the low yield of a planted pasture is characterized by the removal of nutrients from the soil through the requirements of forages and animals (Macedo et al., 2000), soil erosion and nutrient leaching (Inácio et al., 2007), lack of organic matter (Lima et al., 2007) and lack of care with Brachiaria grass in areas of low fertility (Martha Júnior \& Vilela, 2002). In this context, most areas have shown physical and especially chemical alterations in the soil; for productive recovery and, according to Moreira et al. (2005), soil decompaction, combined with the application of limestone and fertilizers, allows greater and faster development of pastures.

Poultry manure is an important organic fertilizer and a good source of nutrients and organic matter. Its decomposition is a complex and slow process (Moreira \& Siqueira, 2006) when applied on the soil, which is influenced by its quality and quantity (Valente et al., 2009), local edaphoclimatic conditions and soil management (Freitas et al., 2012).

It is important to describe and quantify the recovery of soil physical and chemical quality in response to variations in fertilizer dose and mechanical management of these areas. According to Scherer \& Nesi (2009), soil tillage system and fertilizer source influence the availability and distribution of nutrients in the soil profile. In area with recovered pasture, Moreira et al. (2005) observed higher values of $\mathrm{pH}, \mathrm{Ca}^{+2}, \mathrm{Mg}^{+2}$, $\mathrm{P}, \mathrm{K}^{+}, \mathrm{Zn}$, organic matter, macroporosity and total porosity, and lower values of soil density and resistance to penetration.

In sustainable agriculture, various fertilization systems with mechanical management can be adopted in order to maintain soil fertility (Moreti et al., 2007). The use of chiseling implements in pastures with soil physical and chemical problems may promote dual benefits; first, breaking compacted surface layers and second, incorporating poultry manure (Brasil, 2009).

In this context, this study aimed to evaluate physical and chemical alterations in a soil under palisade grass (Brachiaria brizantha $\mathrm{cv}$. Marandu), fertilized with poultry manure and managed with and without chiseling.

\section{MATerial AND Methods}

The experiment was carried out at the Iguatemi Experimental Farm (FEI), of the Maringá State University (UEM), in Maringá-PR, Brazil (23 25’ S; 51 57’ W; 550 m). The prevailing climate is Cfa, mesothermal humid subtropical (Köppen's classification), with mean annual temperature of $22^{\circ} \mathrm{C}$ and predominance of hot summers, with concentrated rains, and winter with low frequency of severe frosts (Figure 1).

The experiment was installed in area of 0.16 ha under palisade grass (Brachiaria brizantha cv. Marandu) with 10 years of grazing, declivity of 5\%, in a dystrophic Red Latosol and layer of $0.0-0.2 \mathrm{~m}$ with $87.25,1.00$ and $11.75 \%$ of sand, silt and clay, respectively.

The soil chemical analysis (Laboratory of Soil and Plant UEM) for the experimental area (0.0-0.20 m), between blocks, showed the following mean values: $\mathrm{pH}\left(\mathrm{H}_{2} \mathrm{O}\right)=6.00 ; \mathrm{C}=8.23$ $\mathrm{g} \mathrm{dm}^{-3} ; \mathrm{P}=6.28 \mathrm{mg} \mathrm{dm}{ }^{-3} ; \mathrm{H}^{+}+\mathrm{Al}^{+3}=2.54 ; \mathrm{Ca}^{+2}=0.87 ; \mathrm{Mg}^{+2}=$

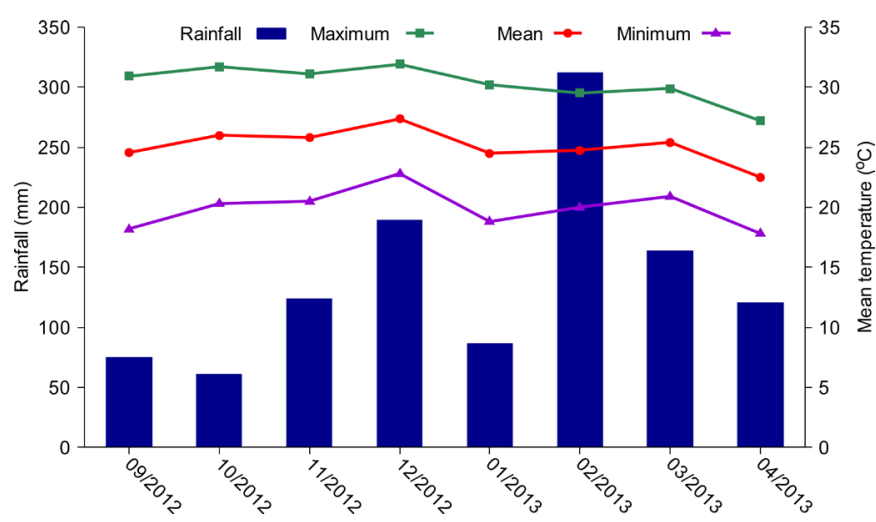

Figure 1. Rainfall and mean air temperatures in the experimental period, from September 2012 to April 2013

$0.57 ; \mathrm{K}^{+}=0.13 \mathrm{cmol} \mathrm{dm}^{-3} ; \mathrm{Fe}=180.86 ; \mathrm{Zn}=4.04 ; \mathrm{Cu}=3.20$; $\mathrm{Mn}=144.21$ and S-SO ${ }_{4}^{2-}=3.25 \mathrm{mg} \mathrm{dm}^{-3}$.

Manure of cage-housed Hy Line W36 laying hens was stored in the shadow for 45 days, covered with a plastic tarp and its chemical analysis (Laboratory of Agro-chemistry and Environment - UEM) showed: organic matter $=60 \%$, Total $\mathrm{N}$ $=6.64 \%, \mathrm{CaO}=3.53 \%, \mathrm{MgO}=5.51 \%, \mathrm{~K}_{2} \mathrm{O}=3.73 \%, \mathrm{P}_{2} \mathrm{O}_{5}=$ $2.41 \%, \mathrm{C} / \mathrm{N}$ ratio $=4.96: 1, \mathrm{Cu}=220.10, \mathrm{Mn}=1226.90, \mathrm{Zn}=$ $368.00 \mathrm{mg} \mathrm{kg}^{-1}$ and $\mathrm{pH}\left(\mathrm{H}_{2} \mathrm{O}\right)=6.98$.

In order to increase soil base saturation in $50 \%, 490 \mathrm{~kg} \mathrm{ha}^{-1}$ of dolomitic limestone ( $32 \% \mathrm{CaO}$ and $15 \% \mathrm{MgO}$ ) were manually applied on the palisade grass in August 2012 and 25 days after a standardization cut using a mower at $0.1 \mathrm{~m}$ from the soil.

The dose of $50 \mathrm{~kg} \mathrm{ha}^{-1}$ of $\mathrm{P}_{2} \mathrm{O}_{5}$ was based on the maintenance of species from the group III (Oliveira, 2003; Costa et al., 2009), present in $2.074 \mathrm{Mg} \mathrm{ha}^{-1}$ of manure. The experiment was set in a randomized block design with four replicates, in a $5 \times 2$ factorial scheme, with five manure doses $(0,1.037,2.074,4.148$, $6.222 \mathrm{Mg} \mathrm{ha}^{-1}$ ) and two soil managements (with and without chiseling). At the end of September, $270 \mathrm{~kg} \mathrm{ha}^{-1}$ of agricultural gypsum were applied and each plot $(6 \times 4 \mathrm{~m})$ received single manure doses. Chiseling was performed at a depth of $0.2 \mathrm{~m}$, using a subsoiler plow (IKEDA - DPT320M), which had a cutting disk in front of each helical bar with inclined tip of steel blades.

The palisade grass was managed with light interception (LI) of 95\% measured with an AccuPAR device (PAR/LAI Ceptometer - Model LP-80) in weekly readings (Trindade et al., 2007) and with mechanical mower lowered at residual height of $0.15 \mathrm{~m}$, and all the biomass was removed from each plot.

Soil physical quality was evaluated at 180 days, in the layers of 0.0-0.2 and 0.2-0.4 m. Using stainless-steel volumetric rings (height and diameter $=0.05 \mathrm{~m}$ ), undisturbed soil samples were collected in the center of each experimental plot and between the tracks of chisel bars in chiseled plots. Each sampled ring was wrapped in aluminum foil to avoid losses of soil and water. In the laboratory, the samples were saturated in trays with a water depth at two thirds of the ring's height. The water content at the matric potential of $-6 \mathrm{kPa}$ was obtained using a tension table; then, the samples were dried in an oven at $105^{\circ} \mathrm{C}$ for $48 \mathrm{~h}$ and weighed for the determination of mass of solids and calculation of soil bulk density (DS). Total soil porosity (Pt) was estimated by the equation: $\mathrm{Pt}=1$ - (soil bulk density/ soil particle density), and the mean value of $2.62 \mathrm{Mg} \mathrm{m}^{-3}$ was 
used for soil particle density. Soil macroporosity (MAC) was estimated by the difference between the water content of the saturated soil and the water content at the matric potential of $-6 \mathrm{kPa}$. Microporosity (MIC) was estimated as the soil water content retained at the matric potential of $-6 \mathrm{kPa}$ (EMBRAPA, 1997).

Saturated hydraulic conductivity (Ks) was determined using a minidisk infiltrometer. After cleaning and leveling the area, the infiltrometer was installed on the soil surface, with a good hydraulic contact between the disk and the soil. Readings were performed every $30 \mathrm{~s}$, until obtaining constant infiltration and the mini-infiltrometer was adjusted to the h0 suction of $0.06 \mathrm{~m}$, due to the sandy texture of the soil (Decagon Device, 2012).

For soil chemical analysis at 180 days, three disturbed soil samples were collected in line with distance of $2 \mathrm{~m}$ in the center of each plot, in the layers of 0.0-0.1, 0.1-0.2 and 0.2-0.4 $\mathrm{m}$, constituting composite samples of each layer. The samples were sent to the Soil and Plant Laboratory of the Maringá State University (UEM) for the determination of $\mathrm{P}$ and $\mathrm{K}^{+}$(extracted with Mehlich 1), $\mathrm{Ca}^{+2}$ and $\mathrm{Mg}^{+2}$ (extracted with $1 \mathrm{~mol} \mathrm{~L}^{-1} \mathrm{KCl}$ ), $\mathrm{H}+\mathrm{Al}$ (SMP method) and $\mathrm{Zn}, \mathrm{Cu}$ and $\mathrm{Mn}$ (extracted with Mehlich 1) (EMBRAPA, 1997).

The analysis of variance was performed using the $R$ statistical package (R Development Core Team, 2009) and the means between managements were compared by Tukey test at 0.05 probability level. The contrast of means by $\mathrm{F}$ test $(\mathrm{P}>$ 0.05 ) evaluated the estimates between the dose zero and each applied dose of poultry manure and regression to linear and quadratic models, using the program Sisvar (Ferreira, 2011).

\section{Results AND Discussion}

Soil density, macroporosity, microporosity, total porosity, in the layers of 0.0-0.2 and 0.2-0.4 m, and hydraulic conductivity on soil surface were not influenced by the increase in poultry manure doses. These results differ from those of Costa et al. (2009), who observed significant effect of poultry litter on soil density (period 1 and layer of $0.2-0.4 \mathrm{~m}$ ) and total porosity (period 2 and layers of 0.0-0.2 and 0.2-0.4 m), and from those of Rós et al. (2013), who observed reduction in soil density from 1.45 to $1.28 \mathrm{~kg} \mathrm{dm}^{-3}$ and increase in total porosity from 0.45 to $0.52 \mathrm{~m}^{3} \mathrm{~m}^{-3}$ between the dose zero and $18 \mathrm{Mg} \mathrm{ha}^{-1}$ of manure incorporated with disk plow.

In the managements with (c) and without (n) chiseling, there was physical alteration in macroporosity (MAC1) in the layer of 0.0-0.2 $\mathrm{m}$ and soil density (DS2), macroporosity (MAC2) and total porosity (Pt2) in the layer of 0.2-0.4 m (Table 1). These results are similar to those reported by Colet et al.
(2009), with increase in macroporosity and total porosity and reduction in soil density, in the layer of 0.0-0.1 m between the tracks of chisel bars, corroborating Tormena et al. (2004), due to the fissures caused in the soil by the passing of chisel bars.

The values of soil density (DS1) in the layer of 0.0-0.2 $\mathrm{m}$ were similar with the management and are below those observed by Fidalski et al. (2008) in dystrophic Red Latosol of medium sandy texture, with value of $1.66 \mathrm{~kg} \mathrm{dm}^{-3}$. In the same period, there was $96.2 \%$ of root dry matter of palisade grass in the layers of $0.0-0.10$ and $0.10-0.20 \mathrm{~m}$, without effect of soil management, which can contribute to the reduction of soil density.

Macroporosity (MAC1) increased in the layer of 0.0-0.2 m with soil chiseling and reached $0.16 \mathrm{~m}^{3} \mathrm{~m}^{-3}$. These results are close to those reported by Araújo et al. (2004), who observed mean value of $0.15 \mathrm{~m}^{3} \mathrm{~m}^{-3}$ for macroporosity and $0.45 \mathrm{~m}^{3} \mathrm{~m}^{-3}$ for total porosity under native forest. Microporosity (MIC1) in the layer of 0.0-0.2 m was similar between the studied soil managements. Similar results were reported by Colet et al. (2009), who observed that soil chiseling did not affect microporosity in the layers of 0.0-0.1 and 0.1-0.2 m. These results are consistent with Silva \& Kay (1997) and show that this attribute is strongly influenced by texture and organic carbon content, suffering little influence from operations with agricultural machines and implements.

Soil chiseling did not increase total porosity (Pt1) in the layer of 0.0-0.2 m between the tracks of chisel bars (Table 1). Similar results were observed by Colet et al. (2009), in the layer of 0.1-0.2 m. The similarity in the values of soil hydraulic conductivity (Ks) between the managements is due to the low soil density and high macroporosity, especially related to the sandy texture of the area, and because the measurements were performed on soil surface, where there was a large amount of residues and roots of palisade grass in the superficial layer.

Chiseling altered soil density (DS2) in the layer of 0.2-0.4 $\mathrm{m}$, with reduction of $6.25 \%$ compared with the soil without chiseling. Although the soil was chiseled until $0.20 \mathrm{~m}$, there is the physical action that goes beyond this depth, causing small fissures in the soil and death of palisade grass roots, which can be attributed to the reduction in DS2 caused by chiseling. Another factor that contributed to it was the increase of 0.29 $\mathrm{g} \mathrm{dm}^{-3}$ of soil in root dry matter with chiseling, in the same sampling period. These results differ from those of Colet et al. (2009), for this physical parameter, which remained constant in the layer of $0.2-0.3 \mathrm{~m}$.

Chiseling in the layer of $0.2-0.4 \mathrm{~m}$ altered restrictive values of macroporosity (MAC2), increased total porosity (Pt2) and did not change microporosity (MIC2) in the layer of 0.2-0.4 m. These variations are similar to those reported by Colet et al.

Table 1. Physical analysis of the soil under palisade grass fertilized with poultry manure with (c) and without (n) chiseling

\begin{tabular}{|c|c|c|c|c|c|c|c|c|c|}
\hline \multirow{2}{*}{ Management } & \multirow{2}{*}{$\begin{array}{c}\text { DS1 } \\
\left(\mathrm{kg} \mathrm{dm}^{-3}\right)\end{array}$} & MAC1 & MIC1 & Pt1 & \multirow{2}{*}{$\begin{array}{c}\mathrm{Ks} \\
\left(\mathrm{cm} \mathrm{s}^{-1}\right)\end{array}$} & \multirow{2}{*}{$\begin{array}{c}\text { DS2 } \\
\left(\mathrm{kg} \mathrm{dm}^{-3}\right)\end{array}$} & MAC2 & MIC2 & Pt2 \\
\hline & & & $\left(m^{3} m^{-3}\right)$ & & & & \multicolumn{3}{|c|}{$\left(m^{3} m^{-3}\right)$} \\
\hline $\mathrm{n}$ & 1.43 & $0.12 \mathrm{a}$ & 0.31 & 0.44 & 0.04 & $1.70 \mathrm{~b}$ & $0.06 \mathrm{a}$ & 0.27 & $0.33 \mathrm{a}$ \\
\hline C & 1.42 & $0.16 \mathrm{~b}$ & 0.30 & 0.47 & 0.07 & $1.60 \mathrm{a}$ & $0.11 b$ & 0.27 & $0.39 \mathrm{~b}$ \\
\hline Mean & 1.43 & 0.14 & 0.31 & 0.45 & 0.06 & 1.65 & 0.06 & 0.27 & 0.26 \\
\hline CV (\%) & 6.53 & 23.44 & 6.37 & 9.29 & 76.75 & 5.75 & 45.61 & 9.99 & 14.17 \\
\hline Error & 0.02 & 0.008 & 0.004 & 0.010 & 0.01 & 0.02 & 0.01 & 0.006 & 0.01 \\
\hline
\end{tabular}

*Means followed by lowercase letters in the column differ by Tukey test $(\mathrm{p}<0.05)$; DS - Soil density; MAC - Macroporosity; MIC - Microporosity; Pt - Total porosity; Ks - Soil hydraulic conductivity; 1 and 2 - layers of 0-0.2 and 0.2-0.4 m; Error - Mean standard error 
(2009), who observed that chiseling reduced macroporosity and total porosity, but did not alter microporosity in the layer of 0.2-0.3 m.

In the layers of 0.0-0.1 and 0.1-0.2 m, fertilizations with poultry manure were significant, with effect on $\mathrm{pH}$ $\left(\mathrm{H}_{2} \mathrm{O}\right)$ (Figure 2A). According to Lima et al. (2007), the increase occurs due to the release of ammonia through the decomposition of organic residue on soil surface. Attributed to the mineralization of organic matter and the action of microorganisms, the quadratic model of $\mathrm{pH}\left(\mathrm{H}_{2} \mathrm{O}\right)$ in the layer of 0.0-0.1 $\mathrm{m}$ showed a maximum point of 7.21.

In the layer of 0.1-0.2 m, pH in $\mathrm{H}_{2} \mathrm{O}$ increased linearly with poultry manure doses and showed lower values compared with the layer of 0.0-0.1 $\mathrm{m}$ (Figure 2A). The maximum dose tested (6.222 $\mathrm{Mg} \mathrm{ha}^{-1}$ ) promoted value of 5.91 , i.e., $6.77 \%$ higher compared with $1.037 \mathrm{Mg} \mathrm{ha}^{-1}$ of poultry manure. For Moreti et al. (2007), with the application of poultry manure in typic dystrophic Red Latosol with clayey texture ( $\mathrm{LVd}), \mathrm{pH}\left(\mathrm{CaCl}_{2}\right)$ was equal to 5.3 in the layer of 0.1-0.2 m. Similar results were observed by Silva Neto et al. (2013), who attributed lower $\mathrm{pH}$ values in the deeper layers to the physical characteristic of the residue and intrinsic characteristics of the soil, which may have leached ammoniacal nitrogen to these layers and intensified the process of nitrification.

There was linear increase in calcium (Ca) contents with the applied doses of poultry manure, which was equal to 0.61 $\mathrm{cmol} \mathrm{dm}^{-3}$ in the layer of 0.0-0.1 m (Figure 2B). Similar results were obtained by Rós et al. (2013), Scherer \& Nesi (2009) and Andreola et al. (2000), with the use of poultry manure. These results corroborate those of Moreti et al. (2007), who observed that, in the layer of 0.0-0.1 m, Ca contents were higher when using poultry manure and poultry manure + half of the mineral fertilization, attributing it to the higher content of organic matter in the poultry manure, which promotes lower leaching of cations.

For potassium $(\mathrm{K})$ in the layer of 0.0-0.1 $\mathrm{m}$, there was an interaction of Dose $\mathrm{x}$ Management (Figure 2C). K contents fitted to a linear model without soil chiseling and were equal

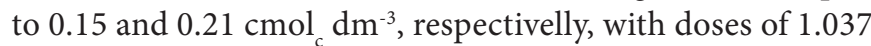
and $6.222 \mathrm{Mg} \mathrm{ha}^{-1}$, an increase of $39.34 \%$. There was no fitting to the proposed models with soil chiseling, due to the increase in macroporosity caused by chisel bars in both analyzed layers, with great mobility of this element and possible losses through leaching (Neves et al., 2009). In addition, this may be due to the percentage of sand, porosity or the fact that $\mathrm{K}$ was immobilized in the soil cover, because of the management adopted in the palisade grass (Andreola et al., 2000).

The contents of phosphorus (P) in the surface layer increased with poultry manure doses (Figure 2D), but did not fit to the proposed regression models, and its mean value was $41.46 \mathrm{mg} \mathrm{dm}^{-3}$. Lima et al. (2007) observed quadratic fit with maximum point at the dose of $14.3 \mathrm{Mg} \mathrm{ha}^{-1}$ of poultry litter and a value corresponding to $20.8 \mathrm{mg} \mathrm{dm}^{-3}$ in the layer of 0.0-0.2 m. In the layers of 0.1-0.2 and 0.2-0.4 m, there was interaction of Dose $x$ Management and the data fitted to linear models; with soil chiseling, there were increases of 8.10 and $3.95 \mathrm{mg} \mathrm{dm}^{-3}$ for the applied manure doses, respectively. The alterations of macroporosity caused by the chisel plow and the
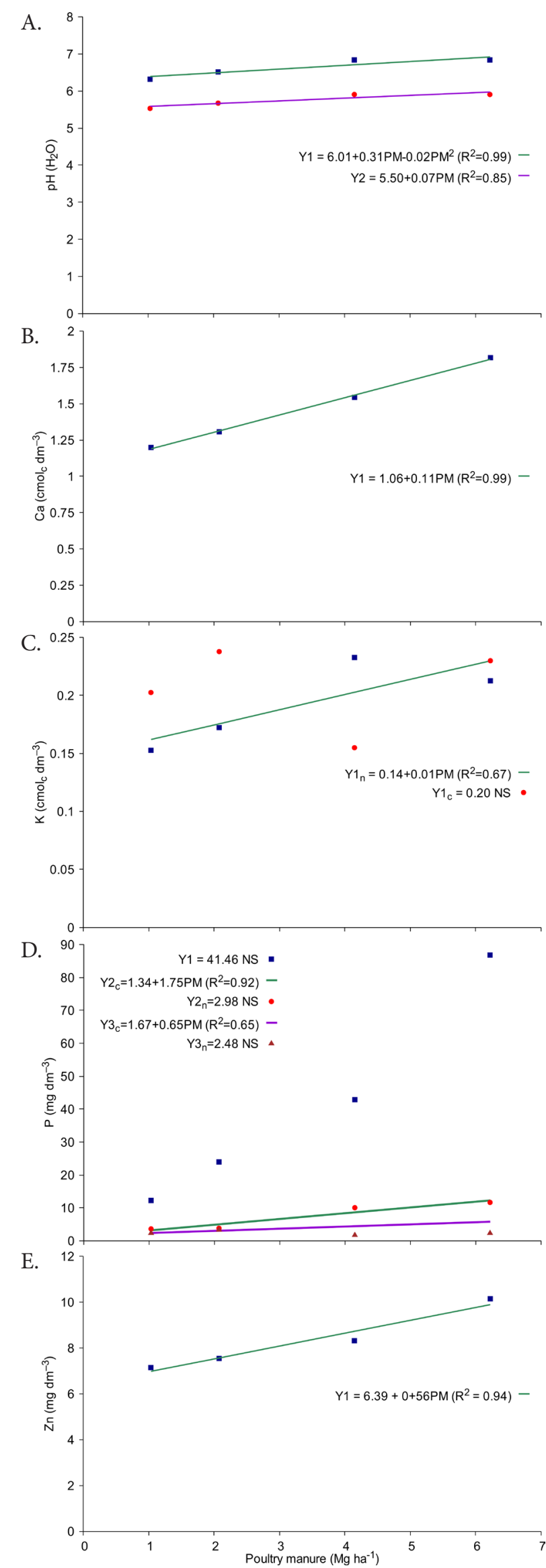

Figure 2. Chemical parameters of the soil under fertilization with poultry manure and management with (C) and without (n) chiseling. $\mathrm{pH}$ in $\mathrm{H}_{2} \mathrm{O}(\mathrm{A})$; $\operatorname{calcium}(\mathrm{B})$; potassium (C); phosphorus (D); zinc (E); Layers of 0-0.1 (1), 0.1-0.2 (2) and 0.2-0.4 m (3) 
high percentage of sand in this soil may have contributed to the movement of $\mathrm{P}$ from the upper layer to the lower ones, despite its low mobility. For Rós et al. (2013), P contents increased linearly with the increment in the incorporated manure doses.

Zinc $(\mathrm{Zn})$ contents in the layer of 0.0-0.1 m increased linearly with the increment in the applied manure dose (Figure 2E). At the dose of $6.222 \mathrm{Mg} \mathrm{ha}^{-1}, \mathrm{Zn}$ contents reached 10.13 $\mathrm{mg} \mathrm{dm}{ }^{-3}$, with increment of $41.75 \%$ in relation to the manure dose of $1.037 \mathrm{Mg} \mathrm{ha}^{-1}$. These results corroborate those reported by Scherer \& Nesi (2009), who observed that poultry manure application in a dystroferric Red Latosol resulted in the highest $\mathrm{Zn}$ contents in the superficial soil layer of 0.0-0.1 m.

The contrast was significant for $\mathrm{pH}$ in $\mathrm{H}_{2} \mathrm{O}$ in the layers of 0.0-0.1 and 0.1-0.2 $\mathrm{m}$ for the manure doses of 2.074, 4.148 and $6.222 \mathrm{Mg} \mathrm{ha}^{-1}$, with estimates in relation to the dose zero of $0.39,-0.71$ and -0.71 and $-0.3,-0.54$ and -0.54 , respectively (Table 2).

The increase in $\mathrm{pH}$ in $\mathrm{H}_{2} \mathrm{O}$ is due to the higher amount of poultry manure applied on surface, which is related to greater release of cations and mineralization of soil organic matter by microorganisms, transforming it into organic substances (organic and humic acids), which attract cations, as well as the release of $\mathrm{NH}_{4}^{+}$, which can have an initial alkaline effect. In the layer of 0.2-0.4 m, there was no significant effect, despite the increase in the doses of poultry manure applied on the palisade grass.

It was not possible to observe significant effect of contrast with the poultry manure dose on potential acidity $(\mathrm{H}+\mathrm{Al})$, despite the effect on $\mathrm{pH}$ in the layers of $0.0-0.1$ and 0.1-0.2 m.

For $\mathrm{Ca}$, the contrast was significant for the poultry manure doses of 2.074, 4.148 and $6.222 \mathrm{Mg} \mathrm{ha}^{-1}$ in the layer of $0.0-0.1 \mathrm{~m}$, with estimates of $-0.29,-0.52$ and $-0.8 \mathrm{cmol} \mathrm{dm}^{-3}$, respectively
(Table 2). In the layer of 0.1-0.2 $\mathrm{m}$, with interaction of Dose $\mathrm{x}$ Management, the contrast was significant for the highest doses without chiseling and not significant for any of the manure doses with chiseling. Despite the increase in poultry manure doses, chiseling increased soil aeration and the action of microorganisms in the decomposition of the existing organic matter, with increase in Ca contents at the lowest doses.

The contrast for $\mathrm{Mg}$ and $\mathrm{K}$ was not significant in the three sampled layers (Table 2), while for P the contrast was significant in the layer of $0.0-0.1 \mathrm{~m}$ for the poultry manure doses of 4.148 and $6.222 \mathrm{Mg} \mathrm{ha}^{-1}$, with estimates in relation to the control of -35.46 and $-79.24 \mathrm{mg} \mathrm{dm}^{-3}$, respectively. These results corroborate those of Moreti et al. (2007), who observed difference of $78.25 \mathrm{mg} \mathrm{dm}^{-3}$ between poultry manure dose and control. In the layer of 0.1-0.2 m, the contrast was significant with interaction of Dose $\mathrm{x}$ Management with soil chiseling for the poultry manure doses of 4.148 and 6.222 $\mathrm{Mg} \mathrm{ha}^{-1}$, and estimates of -7.07 and $-8.67 \mathrm{mg} \mathrm{dm}^{-3}$. Rós et al. (2013) observed increase of $106 \mathrm{mg} \mathrm{dm}^{-3}$ with the application of $18 \mathrm{Mg} \mathrm{ha}^{-1}$ of poultry manure incorporated with a plow, which represented an increment of 2.7 times in relation to the control.

Compared with the dose zero, $\mathrm{Zn}$ showed significant contrast in the layer of $0.0-0.1 \mathrm{~m}$ at the poultry manure doses of 4.148 and $6.222 \mathrm{Mg} \mathrm{ha}^{-1}$, with estimates of -1.98 and $3.81 \mathrm{mg}$ $\mathrm{dm}^{-3}$; in the layer of $0.2-0.4 \mathrm{~m}$, it occurred at the dose of 6.222 $\mathrm{Mg} \mathrm{ha}^{-1}$, with estimate of $-0.52 \mathrm{mg} \mathrm{dm}^{-3}$ (Table 2). Scherer \& Nesi (2009) observed the same trend of $\mathrm{Zn}$ in the soil profile as a function of fertilizer sources and soil tillage system. Ashjaei et al. (2011), studying well drained soil, observed increase of $89.0 \mathrm{mg} \mathrm{dm}^{-3}$ of $\mathrm{Zn}$ content in the layer of $0.0-2.5 \mathrm{~cm}$, in comparison to the control, with application of $5 \mathrm{Mg} \mathrm{ha}^{-1}$ of poultry litter per year.

Table 2. Chemical analysis of the soil under palisade grass fertilized with doses of poultry manure and managed with (c) and without (n) chiseling, at 180 days

\begin{tabular}{|c|c|c|c|c|c|c|c|c|c|}
\hline \multirow{2}{*}{\multicolumn{2}{|c|}{$\begin{array}{c}\text { Parameter } \\
\text { Laver }\end{array}$}} & \multicolumn{4}{|c|}{ Dose (Mg ha-1) } & \multirow{2}{*}{0} & \multirow{2}{*}{ Mean } & \multirow{2}{*}{ CV (\%) } & \multirow{2}{*}{ Effect } \\
\hline & & 1.037 & 2.074 & 4.148 & 6.222 & & & & \\
\hline \multirow{3}{*}{$\mathrm{pH}\left(\mathrm{H}_{2} \mathrm{O}\right)$} & 1 & 6.32 NS & 6.51 & 6.83 & 6.83 & 6.12 & 6.52 & 3.40 & * \\
\hline & 2 & $5.53^{\mathrm{NS}}$ & 5.67 & 5.91 & 5.91 & 5.37 & 5.68 & 4.88 & * \\
\hline & 3 & 5.66 NS & $5.66^{\text {NS }}$ & $5.55^{\mathrm{NS}}$ & $5.56^{\mathrm{NS}}$ & 5.59 & 5.60 & 5.46 & \\
\hline \multirow{3}{*}{$\mathrm{H}+\mathrm{Al}\left(\mathrm{cmol}_{\mathrm{c}} \mathrm{dm}^{-3}\right)$} & 1 & $2.36^{\mathrm{NS}}$ & $2.26^{\mathrm{NS}}$ & $1.98^{\mathrm{NS}}$ & $2.13^{\mathrm{NS}}$ & 2.35 & 2.21 & 13.58 & \\
\hline & 2 & 2.38 NS & $2.32^{\text {NS }}$ & $2.25^{\mathrm{NS}}$ & $2.22^{N S}$ & 2.45 & 2.32 & 7.43 & \\
\hline & 3 & 3.08 NS & $3.14^{\text {NS }}$ & 3.14 NS & 3.17 NS & 3.14 & 3.13 & 5.98 & \\
\hline \multirow{4}{*}{$\mathrm{Ca}\left(\mathrm{cmol}_{\mathrm{c}} \mathrm{dm}^{-3}\right)$} & 1 & $1.20^{\mathrm{NS}}$ & 1.31 & 1.54 & 1.82 & 1.02 & 1.37 & 15.84 & * \\
\hline & 2 & 0.59 NS & $0.54^{\text {NS }}$ & $0.53^{\text {NS }}$ & 0.71 & 0.44 & 0.61 & 20.92 & $\star \star n$ \\
\hline & 2 & 0.50 NS & $0.63^{N S}$ & $0.90^{N S}$ & $0.72^{\text {NS }}$ & 0.64 & 0.61 & 20.92 & ${ }^{\star *} \mathrm{C}$ \\
\hline & 3 & $0.55^{\text {NS }}$ & 0.54 NS & $0.52^{\text {NS }}$ & $0.66^{\text {NS }}$ & 0.62 & 0.57 & 23.21 & \\
\hline \multirow{3}{*}{$\mathrm{Mg}\left(\mathrm{cmol}_{\mathrm{c}} \mathrm{dm}^{-3}\right)$} & 1 & $0.87^{\mathrm{NS}}$ & $0.88^{N S}$ & $0.91^{N S}$ & $1.06^{\mathrm{NS}}$ & 0.70 & 0.88 & 28.99 & \\
\hline & 2 & 0.26 NS & 0.28 NS & 0.34 NS & 0.32 NS & 0.23 & 0.28 & 30.98 & \\
\hline & 3 & 0.26 NS & 0.26 NS & $0.21^{\mathrm{NS}}$ & $0.27^{\mathrm{NS}}$ & 0.28 & 0.25 & 24.79 & \\
\hline \multirow{3}{*}{$\mathrm{K}\left(\mathrm{cmol}_{\mathrm{c}} \mathrm{dm}^{-3}\right)$} & 1 & $0.18^{N S}$ & $0.21^{\mathrm{NS}}$ & $0.19^{N S}$ & $0.22^{N S}$ & 0.16 & 0.19 & 31.23 & \\
\hline & 2 & 0.08 NS & $0.14^{\text {NS }}$ & $0.11^{\text {NS }}$ & $0.12^{\text {NS }}$ & 0.09 & 0.10 & 45.61 & \\
\hline & 3 & 0.06 NS & $0.10^{\text {NS }}$ & $0.07^{N S}$ & 0.09 NS & 0.05 & 0.07 & 64.94 & \\
\hline \multirow{4}{*}{$P\left(\mathrm{mg} \mathrm{dm}^{-3}\right)$} & 1 & $12.23^{\mathrm{NS}}$ & $23.95^{\mathrm{NS}}$ & 42.95 & 86.73 & 7.49 & 34.66 & 89.81 & * \\
\hline & 2 & 2.33 NS & $3.78^{N S}$ & $2.38^{N S}$ & $3.48^{N S}$ & 1.03 & 4.49 & 58.71 & $* * n$ \\
\hline & 2 & 3.52 NS & $3.82^{N S}$ & 10.02 & 11.62 & 2.95 & 4.49 & 58.71 & ${ }^{\star \star} \mathrm{C}$ \\
\hline & 3 & 2.56 NS & 3.39 NS & 2.26 NS & $4.53^{\mathrm{NS}}$ & 2.65 & 3.07 & 53.25 & \\
\hline \multirow{3}{*}{$\mathrm{Zn}\left(\mathrm{mg} \mathrm{dm}^{-3}\right)$} & 1 & $7.15^{\mathrm{NS}}$ & $7.55^{\mathrm{NS}}$ & 8.31 & 10.14 & 6.33 & 7.89 & 24.89 & * \\
\hline & 2 & 2.76 NS & $3.16^{\text {NS }}$ & 3.63 NS & 3.40 NS & 2.46 & 3.08 & 36.51 & \\
\hline & 3 & 1.14 NS & $1.28 \mathrm{NS}$ & $1.36^{\mathrm{NS}}$ & 1.64 & 1.12 & 1.30 & 26.56 & * \\
\hline
\end{tabular}

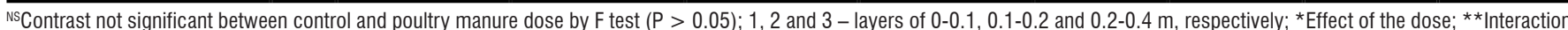
of Dose x Management with (c) and without (n) chiseling 


\section{Conclusions}

1. Fertilization with poultry manure did not alter soil density, macroporosity, microporosity, total porosity or saturated hydraulic conductivity.

2. Mechanical chiseling management reduced soil density and increased macroporosity and total porosity.

3. Poultry manure contributed to the increase of $\mathrm{pH}$ in $\mathrm{H}_{2} \mathrm{O}$ and contents of $\mathrm{P}, \mathrm{Ca}$ and $\mathrm{Zn}$ in the superficial layer of 0.0-0.1 m.

4. The mechanical management of soil chiseling increased $\mathrm{P}$ contents in the layers of 0.1-0.2 and 0.2-0.4 m.

\section{Literature Cited}

Andreola, F.; Costa, L. M.; Mendonça, E. S., Olszevski, N. Propriedades químicas de uma Terra Roxa Estruturada influenciadas pela cobertura vegetal de inverno e pela adubação orgânica e mineral. Revista Brasileira de Ciência do Solo, v.24, p.609-620, 2000. http:// dx.doi.org/10.1590/S0100-06832000000300014

Araújo, M. A.; Tormena, C. A.; Silva, A. P. Propriedades físicas de um latossolo vermelho distrófico cultivado e sob mata nativa. Revista Brasileira de Ciência do Solo, v.28, p.337-345, 2004. http://dx.doi. org/10.1590/S0100-06832004000200012

Ashjaei, S.; Miller, W. P.; Cabrera, M. L.; Hassan, S. M. Arsenic in soils and forages from poultry litter-amended pastures. International Journal of Environmental Research and Public Health, Basel, v.8, p.1534-1546, 2011. http://dx.doi.org/10.3390/ijerph8051534

Brasil. Ministério da Agricultura, Pecuária e Abastecimento. Instrução Normativa n.25, de 23 de julho de 2009. Diário Oficial da República Federativa do Brasil, Brasília, DF, 28 de julho de 2009. Seção 1, p.20, 2009.

Colet, M. J.; Sverzut, C. B.; Weirich Neto, P. H.; Souza, Z. M. de. Alteração em atributos físicos de um solo sob pastagem após escarificação. Ciência e Agrotecnologia, v.33, p.361-368, 2009. http://dx.doi.org/10.1590/S1413-70542009000200001

Costa A. M.; Borges, E. N.; Silva, A de A.; Nolla, A.; Guimarães, E. C. Potencial de recuperação física de um Latossolo Vermelho, sob pastagem degradada, influenciado pela aplicação de cama de frango. Ciência e Agrotecnologia, v.33, p.1991-1998, 2009. http:// dx.doi.org/10.1590/S1413-70542009000700050

Decagon Device. Inc. Mini disk infiltrometer: User's manual version10. Decagon Devices, Inc.2365 NE Hopkins Court Pullman, 2012, 26p.

EMBRAPA - Empresa Brasileira de Pesquisa agropecuária. Manual de métodos de análise de solos. 2.ed. Rio de Janeiro: EMBRAPA, 1997. 212p.

Ferreira, D. F. Sisvar: a computer statistical analysis system. Ciência e Agrotecnologia, v.35, p.1039-1042, 2011.

Fidalski, J.; Tormena, C. A.; Cecato, U.; Barbero, L. M.; Lugão, S. M. B.; Costa, M. A. T. Qualidade física do solo em pastagem adubada e sob pastejo contínuo. Pesquisa Agropecuária Brasileira, v.43, p.15831590, 2008. http://dx.doi.org/10.1590/S0100-204X2008001100018

Freitas, M. do S. C. de; Araújo, C. A. de S.; Silva, D. J. Decomposição e liberação de nutrientes de estercos em função da profundidade e do tempo de incorporação. Revista Semiárido de Visu, v.2, p.150-161, 2012.

Inácio, E. S. B.; Cantalice, J. R. B., Nacif, P. G. S.; Araujo, Q. R. de; Barreto, A. C. Quantificação da erosão em pastagem com diferentes declives na microbacia do Ribeirão Salomea. Revista Brasileira de Engenharia Agrícola e Ambiental, v.11, p.355-360, 2007. http://dx.doi.org/10.1590/S1415-43662007000400002
Lima, J. J.; Mata, J. D. V.; Neto, R. P.; Scapim, C. A. Influência da adubação orgânica nas propriedades químicas de um Latossolo Vermelho distrófico e na produção de matéria seca de Brachiaria brizantha cv. Marandu. Acta Scientiarum Agronomy, v.29, p.715719, 2007. http://dx.doi.org/10.4025/actasciagron.v29i5.754

Macedo, M. C. M.; Kichel, A. N.; Zimmer, A. H. Degradação e alternativas de recuperação e renovação de pastagens. Campo Grande: Embrapa CNPGC, 2000. 4p. Comunicado Técnico, 62

Martha Júnior, G. B.; Vilela, L. Pastagens no Cerrado: Baixa produtividade pelo uso limitado de fertilizantes em pastagens. Planaltina: Embrapa Cerrados, 2002. 32p. Documentos, 50.

Moreira, F. M. S.; Siqueira, J. O. Microbiologia e bioquímica do solo. Lavras: UFLA, 2006. 729p.

Moreira, J. A. A.; Oliveira, I. P.; Guimarães, C. B.; Stone, L. F. Atributos químicos e físicos de um latossolo vermelho distrófico sob pastagens recuperada e degradada. Pesquisa Agropecuária Tropical, v.35, p.155-161. 2005.

Moreti, D.; Alves, M. C.; Filho, W. V. V.; Carvalho, M. P. Atributos químicos de um Latossolo Vermelho sob diferentes sistemas de preparo, adubações e plantas de cobertura. Revista Brasileira de Ciência do Solo, v.31, p.167-175, 2007. http://dx.doi.org/10.1590/ S0100-06832007000100017

Neves, L. S. das; Ernani, P. R.; Simonete, M. A. Mobilidade de potássio em solos decorrente da adição de doses de cloreto de potássio. Revista Brasileira de Ciência do Solo, v.33, p.25-32, 2009. http:// dx.doi.org/10.1590/S0100-06832009000100003

Oliveira, E. L. de. Sugestão de adubação e calagem para culturas de interesse econômico no Estado do Paraná. Londrina: IAPAR, 2003. 30p.

R Development Core Team. R: A language and environment for statistical computing. Vienna: R Foundation for Statistical Computing, 2009. 409p.

Rós, A. B.; Hirata, A. C. S.; Narita, N. Produção de raízes de mandioca e propriedades química e física do solo em função de adubação com esterco de galinha. Pesquisa Agropecuária Tropical, v.43, p.247254, 2013. http://dx.doi.org/10.1590/S1983-40632013000300001

Scherer, E. E.; Nesi, C. N. Características químicas de um Latossolo sob diferentes sistemas de preparo e adubação orgânica. Bragantia, v.68, p.715-721, 2009. http://dx.doi.org/10.1590/S0006-87052009000300019

Silva, A. P.; Kay, B. D. Estimating the least limiting water range of soils from properties and management. Soil Science Society of America, v.61, p.877-883, 1997. http://dx.doi.org/10.2136/ sssaj1997.03615995006100030023x

Silva Neto, S. P. da; Santos, A. C. dos; Silva, J. E. C. da; Dim, V. P.; Araújo, A. dos S. Atributos químicos de um Neossolo Quartzarênico sob capim-marandu adubado com resíduo líquido de frigorífico. Semina: Ciências Agrárias, v.34, p.1099-1110, 2013. http://dx.doi.org/10.5433/1679-0359.2013v34n3p1099

Tormena, C. A.; Friedrich, R.; Pintro, J. C.; Costa, A. C. S; Fidalski, J. Propriedades físicas e taxa de estratificação de carbono orgânico num latossolo vermelho após dez anos sob dois sistemas de manejo. Revista Brasileira de Ciência do Solo, v.28, p.1023-1031, 2004. http://dx.doi.org/10.1590/S0100-06832004000600011

Trindade, J. K.; Silva, S. C. da; Souza Júnior, S. J.; Giacomini, A. A.; Zeferino, C. V.; Guarda, V. D. A.; Carvalho, P. C. de F. Composição morfológica da forragem consumida por bovinos de corte durante o rebaixamento do capim Marandu submetido a estratégias de pastejo rotativo. Pesquisa Agropecuária Brasileira, v.42, p.883890, 2007. http://dx.doi.org/10.1590/S0100-204X2007000600016

Valente, B. S.; Xavier, E. G., Morselli, T. B. G. A.; Jahnke, D. S., Brum Jr.; B. de S., Cabrera, B. R.; Moraes, P. de O.; Lopes, D. C. N. Fatores que afetam o desenvolvimento da compostagem de resíduos orgânicos. Archivos de Zootecnia, v.58, p.59-85, 2009. 